\title{
INTRODUCING LEADERSHIP LEARNING IN ENGINEERING CLASSROOMS
}

\author{
"Evans G.J., *Reeve D.W., and ${ }^{* *}$ Simpson A.E. \\ Faculty of Applied Sciences and Engineering, University of Toronto, Canada \\ greg.evans@utoronto.ca
}

\section{INTRODUCTION}

Leadership development is an emerging challenge and opportunity for engineering educators [1]. Leadership education within Engineering at the University of Toronto is being driven by the Engineering Leaders of Tomorrow Program (LOT) [2]. This program draws from a variety of influences [e.g. 3-5] to offer students a range of curricular and cocurricular programming and engage them at multiple levels.

\section{METHODS}

In September of 2008, Engineering Leaders of Tomorrow (LOT) launched a leadership infusion initiative to provide all engineering students with a basic understanding and awareness of the nature of leadership. Six infusion lectures were designed for delivery as one-hour guest-lectures within existing engineering courses. The goal is that every undergraduate student will attend all six lectures before graduating, thus offering students a foundation of leadership knowledge. This foundation will provide a framework for ongoing learning through life experiences while at university and after graduation.

The six topics covered in the lectures are: Engineering Leadership, Self-Leadership, Leading in Teams, Developing Vision, Leadership and Citizenship, and Reflection and Personal Growth. Table 1 summarizes the learning objectives of the infusion lectures. The structure is based on the four leadership themes - knowing who you are, how to work effectively with others, where you want to go, and how to translate ideas into action - supported by an introductory lecture and a summary lecture. The summary lecture describes tools for structured reflection, drawn from the earlier lectures, so as to promote continuous learning and personal growth. Together, the six lectures seek to provide students with a basic understanding of, and appreciation for, leadership and leadership-learning.

\begin{tabular}{|c|c|}
\hline Lecture & Learning Objectives \\
\hline 1 & $\begin{array}{l}\text { - Connect how leadership relates to Engineering } \\
\text { - Use a framework to describe the nature of leadership } \\
\text { - Describe how self-awareness relates to leadership } \\
\text { - Identify and state their values, talents and passions } \\
\text { - Identify their leadership style }\end{array}$ \\
\hline 2 & $\begin{array}{l}\text { - Use self-awareness to relate their decisions and actions } \\
\text { - Describe emotional intelligence (EQ) } \\
\text { - Identify an EQ competency they want to develop } \\
\text { - Identify if they are an introvert or extrovert }\end{array}$ \\
\hline 3 & $\begin{array}{l}\text { - Describe the stages of team development } \\
\text { - Describe how their leadership may affect group } \\
\text { function } \\
\text { - Explain the roles of trust and conflict in teamwork } \\
\text { - Describe behavioural complexity }\end{array}$ \\
\hline 4 & $\begin{array}{l}\text { - Connect how leadership links to vision } \\
\text { - Critically analyze a vision statement } \\
\text { - Create a compelling vision statement } \\
\text { - Use vision to help implement change }\end{array}$ \\
\hline 5 & $\begin{array}{l}\text { - Describe elements of citizenship and global citizenship } \\
\text { - Connect citizenship to the Social Change Model of } \\
\text { Leadership Development } \\
\text { - Use a framework to put inspiration into action }\end{array}$ \\
\hline 6 & $\begin{array}{l}\text { - Apply reflection to experiential learning } \\
\text { - Utilize reflection to build leadership capacity } \\
\text { - Pursue lifelong learning through structured reflection } \\
\text { - Develop and articulate their personal vision }\end{array}$ \\
\hline
\end{tabular}

Table 1: Learning Objectives of the six Leadership Infusion Lectures

The lectures consist of PowerPoint presentations combined with individual exercises. Visual frameworks and individual assessment exercises are common element of all the lectures. Delivery as guest lectures within unrelated courses is not optimal for learning but offers the opportunity to reach students who may choose not to participate in the many optional co- and extra-curricular LOT activities.

\section{RESULTS}

The series was introduced in 2008-09 when 21 lectures were offered to $\sim 2400$ students in classes of 15 to 700. In 2009-10, 17 lectures were delivered with $\sim 2200$ students attending. At the end of each lecture, students were given anonymous feedback forms to complete. Students were asked to rank the following statements from low to high on a Likert scale (Table 1). Evaluations were not done after some lectures due to time constraints and typically they were only completed by $\sim 50 \%$ of the students present.

\begin{tabular}{|l|c|c|}
\hline \multicolumn{1}{|c|}{ Question } & $\begin{array}{c}\mathbf{2 0 0 8 - 0 9} \\
\mathrm{n}=697\end{array}$ & $\begin{array}{c}\mathbf{2 0 0 9 - 1 0} \\
\mathrm{n}=677\end{array}$ \\
\hline $\begin{array}{l}\text { How valuable was this } \\
\text { presentation to you? }\end{array}$ & $7.3 \pm 0.2$ & $7.5 \pm 0.3$ \\
\hline $\begin{array}{l}\text { How much has this session } \\
\text { increased your interest in } \\
\text { learning about leadership at } \\
\text { U of T? }\end{array}$ & $6.8 \pm 0.2$ & $6.6 \pm 0.2$ \\
\hline $\begin{array}{l}\text { How much has this session } \\
\text { increased your interest in } \\
\text { learning about leadership } \\
\text { after graduation }\end{array}$ & $7.3 \pm 0.2$ & $7.0 \pm 0.2$ \\
\hline $\begin{array}{l}\text { How well was this session } \\
\text { delivered }\end{array}$ & $8.6 \pm 0.09$ & $8.2 \pm 0.1$ \\
\hline
\end{tabular}

Table 2: Student evaluation of the infusion lectures on a Likert scale of 1 (low) to 10 (high). The data for 2008-09 were adjusted from a sevenpoint to a ten-point scale to facilitate comparison (values are mean $\pm 95 \%$ confidence interval)

\section{DISCUSSION}

Feedback on the delivery of the lectures was quite positive in both years. The students also indicated that they found the lectures to be valuable. Their interest in learning about leadership was lower but still positive. Interestingly, the students indicated that they were more interested in learning about leadership after graduation then while they were in university. This difference possibly reflects the high time-demand of the engineering curriculum which discourages students from thinking about anything beyond immediate assignments. Thus it was concluded that the students valued leadership education and were more interested in pursing it after they graduated. The Engineering Leaders of Tomorrow Program envisions an engineering education that is a lifelong foundation for transformational leaders and outstanding citizens. The frameworks and tools within these lectures are intended to help build this foundation so as to promote growth from life experiences, both while on campus and more importantly after graduation.

\section{ACKNOWLEDGEMENT}

The authors are grateful to Parnian Jadidian and Brian Tran for their help with compiling and analyzing the evaluation data.

\section{REFERENCES}

1. Farr J.V and D.M. Brazil Engrg Manag. J. 2009 21(1), 3-8.

2. www.lot.engineering.utoronto.ca

3. Goleman, D. Emotional Intelligence: Why it Can Matter More than IQ, Random House, New York, 1995

4. Kouzes J.M and B.Z. Posner The Leadership Challenge: How To Get Extraordinary Things Done In Organizations, Jossey-Bass, 1987

5. Komives S.R. N. Lucas and T.R McMahan Exploring Leadership For College Students Who Want to Make a Difference John Wiley \& Sons Inc 1998

* Dept. of Chemical Engineering and Applied Chemistry and

Engineering Leaders of Tomorrow

** Engineering Leaders of Tomorrow 